\title{
Phenolic contents of lettuce, strawberry, raspberry, and blueberry crops cultivated under plastic films varying in ultraviolet transparency
}

Article

Ordidge, M., García-Macías, P., Battey, N. H., Gordon, M. H., Hadley, P., John, P., Lovegrove, J. A., Vysini, E. and Wagstaffe, A. (2010) Phenolic contents of lettuce, strawberry, raspberry, and blueberry crops cultivated under plastic films varying in ultraviolet transparency. Food Chemistry, 119 (3). pp. 1224-1227. ISSN 0308-8146 doi:

https://doi.org/10.1016/j.foodchem.2009.08.039 Available at https://centaur.reading.ac.uk/4635/

It is advisable to refer to the publisher's version if you intend to cite from the work. See Guidance on citing.

To link to this article DOI: http://dx.doi.org/10.1016/j.foodchem.2009.08.039

Publisher: Elsevier

All outputs in CentAUR are protected by Intellectual Property Rights law, including copyright law. Copyright and IPR is retained by the creators or other copyright holders. Terms and conditions for use of this material are defined in the End User Agreement. 


\section{www.reading.ac.uk/centaur}

\section{CentAUR}

Central Archive at the University of Reading

Reading's research outputs online 


\title{
DRAFT \\ Phenolic contents of lettuce, strawberry, raspberry, and blueberry crops cultivated under plastic films varying in ultraviolet transparency
}

\author{
Matthew Ordidge ${ }^{1}$, Paulina García-Macías ${ }^{2}$, Nicholas H. Battey ${ }^{1}$, Michael H. Gordon ${ }^{2}$, \\ Paul Hadley ${ }^{1}$, Philip John*, ${ }^{1}$ Julie A. Lovegrove ${ }^{2}$, Eleni Vysini ${ }^{1}$ and Alexandra \\ Wagstaffe $^{1}$ \\ ${ }^{1}$ School of Biological Sciences, Harborne Building, University of Reading, Whiteknights, \\ Reading, RG6 6AS, UK \\ ${ }^{2}$ Hugh Sinclair Unit of Human Nutrition, School of Chemistry, Food Biosciences and \\ Pharmacy, University of Reading, Whiteknights, Reading, RG6 6AP, UK
}

Keywords: anthocyanins, blueberries, flavonoids, lettuce, polythene tunnels, strawberries, raspberries, ultraviolet

*Corresponding author (telephone +44-1183788098; fax 44-118378160; email p.john@ reading.ac.uk)

Abstract/Summary (to be done)

\section{Introduction}

In temperate climates soft fruit and salad crops are increasingly being grown commercially under the protective cover provided by plastic tunnels. For example in the UK, $80 \%$ of the strawberry crop is now grown under polythene (Wagstaffe et al, 2008). The quality of light reaching plants is well known to affect plant growth and development, and the employment of plastic films would therefore be expected to affect crop quality and production.

While the standard polythene film used for tunnels screens a proportion of the UV, films which differ in their ability to transmit UV light whilst retaining unaltered the available photosynthetically active radiation (PAR) are now available. The effect of altering the level of UV light in growing systems has been found to affect the pigment and colourless phytochemical contents of some crop plants. For example, the total phenolic and phenolic acid contents of tomato fruits are $20 \%$ higher when plants are cultivated under UV transparent compared with UV blocking plastic films (Luthria et al., 2006).

Soft fruit and salads are significant sources of anthocyanins and other flavonoids, which are important dietary components helping to reduce the risk of chronic disease (Hannum 2004; Beattie et al, 2005). For example, in France, based on average content and on consumption data, it has been shown that strawberry and lettuce are among the main sources of polyphenols from fruit and vegetables respectively (Brat et al, 2006). The levels of secondary compounds in soft fruit have previously been shown to be influenced by environmental factors including temperature (Wang and Zheng, 2001), carbon dioxide 
concentration (Gil Et al, 1997; Wang et al., 2003), climate (Kalt et al, 2001), growing media (Wang and Lin, 2003), ripening stage and genotype (Wang and Lin, 2000; Moyer etal, 2002). However the effect of cultivation under different UV regimes has not been determined.

The main aim of the present paper is to determine the levels of health-related phytochemicals in strawberry, raspberry and blueberry fruit grown under plastic films of three different UV transparencies. We also extend previous work on the phenolic composition of lettuce (Garcia-Macias et al., 2007; Tsormpatsidis et al., 2008) grown under these conditions, comparing red with non-red leaf lettuce. All crops were grown and harvested in near commercial conditions in order to make the results relevant to commercial production.

\section{Materials and Methods}

Plant Material and growing conditions. All plants were grown in 2006 (year 1) and 2007 (year 2) at the Shinfield Field Unit (University of Reading, UK). Lettuce (Lactuca sativa L. Lollo Rosso type, red leaf, cv. Revolution; and Lollo Biondo type, green leaf, cv. Bergamo) was grown from seed as described previously (Garcia Macias et al, 2007). Strawberries (Fragaria x ananassa Duch. cvs. Elsanta, Everest) were grown in peat bags and raspberries (Rubus idaeus L. cvs. Tulameen, Joan Squire) and blueberries (Vaccinium corymbosum L. cv. Bluecrop) were grown in pots of substrate specific to each crop (Bulrush Horticulture Ltd, UK). Strawberry and raspberry plants were irrigated using a fertiliser mix optimised for peat based soft fruit growing and blueberries were fed with a standard commercial blueberry fertiliser (Hortifeeds, Lincoln, UK). The irrigation timing, fertiliser concentration and $\mathrm{pH}$ were all controlled automatically. Harvesting was carried out based on commercial picking standards. Strawberries were picked on a three day cycle (picking on day 3), raspberries were picked on a two day cycle and blueberries were picked on a seven day cycle.

All plants were grown in blocks in a multi-span, open-sided tunnel ( 7 spans of $6.5 \mathrm{x}$ $75 \mathrm{~m})$. Three experimental blocks per treatment were laid out as equally sized areas down the length of each of three tunnel spans. The spectral properties of the films were as described previously (Garcia-Macias et al., 2007). All three films contained the infra-red reducing and light diffusing components of Luminance THB (British Polythene Industries PLC, Greenock, UK). The UV Block film blocked between $94 \%$ and $99 \%$ of light in UV-B wavelengths and 96-99\% of light in UV-A wavelengths up to $380 \mathrm{~nm}$. The UV Low film, which represented standard polythene film used commercially, blocked between $74 \%$ and $87 \%$ of light in UV-B wavelengths and between $23 \%$ and $78 \%$ of light in UV-A wavelengths. The UV Window film transmitted between $60 \%$ and $78 \%$ of UV wavelengths between 260 and $400 \mathrm{~nm}$.

Chemicals. Folin-Ciocalteu reagent, quercetin, ellagic acid, quercetin, gallic acid and caffeic acid were purchased from Sigma-Aldrich Company Ltd. (Poole, UK), and anthocyanidins from Polyphenols Laboratories (Sandnes, Norway). 
Extraction. Lettuce was extracted on the day of harvest as described (Garcia-Macias et al, 2007). Soft fruit was blended in a food processor on the day of harvest and kept at $20^{\circ} \mathrm{C}$ until extraction. Frozen purée was thawed and $1 \mathrm{~g}$ was extracted with $20 \mathrm{~mL}$ of acidified methanol $(1 \% \mathrm{HCl})$. The mixture was left for $20 \mathrm{~h}$ at $6^{\circ} \mathrm{C}$ in the dark, the extracts vacuum filtered through Whatman No.1 $(11 \mu \mathrm{m})$, and kept at $-20^{\circ} \mathrm{C}$ until analysis.

Determinations. The total phenolic content, expressed as gallic acid equivalents (GAE), was determined by the Folin-Ciocalteu method (Singleton and Rossi, 1965) and flavonoids and phenolic acids by High-Performance Liquid Chromatography, all as described previously (Garcia-Macias et al, 2007).

Statistical Analysis. The program used for statistical analysis was Genstat. Differences among the means were compared between treatments using one-way analysis of variance. Differences at $P<0.05$ were considered to be significant.

\section{Results and Discussion}

Lettuce. In the red lettuce, Lollo Rosso, as found previously (Garcia-Macias et al, 2007) total phenolics, anthocyanin, luteolin and quercetin levels were all raised by moving from UV Block to UV Low and to UV Window (Table 1). On the other hand, the related green lettuce, Lollo Biondo, cultivated under the same conditions, showed virtually no phytochemical responses to the same variation in UV levels (Table 1). The fact that Lollo Biondo lettuce does not greatly raise phenolic levels in response to UV conditions that enormously raise phenolic levels in Lollo Rosso lettuce suggests that the phenolics in Lollo Rosso are not accumulated as a protection against UV damage, but are the manifestation of an unspecified adaptive response to non-damaging levels of UV. The commercial implication of this suggestion is that the dramatic increase in healthbeneficial phenolic compounds noted previously with Lollo Rosso grown under UVtransparent plastic (Garcia-Macias et al, 2007; Tsormpatsidis et al, 2007) may not be apparent among other lettuce cultivars, either of the green or red types.

Soft fruit. Overall, the phenolic levels of strawberries, raspberries, and blueberries were unresponsive to the UV transparency of the plastic film under which the crops were grown (Table 2). With both cultivars of strawberry tested, the June-bearer Elsanta and the ever-bearer Everest, a reduction in total phenolics, anthocyanin and ellagic acid could be observed when crops were grown under UV blocking film, but the effect was not observed with all crops under all conditions. With neither of the two cultivars of raspberry, the summer-fruiting cv Tulameen, and the fall-fruiting cv Joan Squire, did the UV transparency of the films have any effect on the phenolic contents of the fruit (Table 2). Again with blueberry, there was no consistent effect of the UV transparency of the plastic film (Table 2).
Comment [a3]: Paulina: still correct ? Comment [a4]: Paulina correct ? 
Thus we find that the soft fruit tested resemble the green lettuce type Lollo Biondo and differ from the red lettuce type Lollo Rosso and the tomato fruits examined elsewhere (Luthria et al, 2006), in that the soft fruit are unresponsive to the range of ambient UV levels provided by plastic films of differing UV transparency. The generality of this finding needs to be qualified by two considerations. First, the cultivars chosen for the present study are commercial varieties, which are likely to have been bred inter alia for stability of colour (and thus anthocyanin levels) under a variety of climatic conditions, and other varieties, more variable and therefore less useful commercially, may be more responsive to UV. Second, the UK climate is not noted for high solar UV levels, and higher UV irradiance levels than those experienced in the present experiments may lead to enhanced phenolic contents in soft fruit.

The soft fruit has a much lower surface area: volume ratio than the lettuce, and this may at least partly explain the lack of effect in soft fruit compared to Lollo Rosso lettuce. The depth of penetration of UV light into strongly coloured fruit is probably very limited, and consequently anthocyanin biosynthesis in most of the fruit would be unaffected by UV light even if it has an effect on the outer tissues of the fruit. The situation with Lollo Biondo is different since the lack of response indicates that the lettuce lacks the required enzymes for anthocyanin biosynthesis.

The implication of the present experiments for commercial production of soft fruit is that, at least for temperate climates such as that of the UK, crops grown in tunnels under polythene film that partially (or completely) blocks UV are as rich in health-beneficial phenolics as crops grown under UV transparent film. Cultivation of soft fruit crops under polythene films provides advantages of extended season and enhanced crop quality (Wagstaffe et al, 2008), and we now show that these advantages are not accompanied by a phytochemical penalty.

\section{Acknowledgements}

We thank British Polythene Industries Plc, and the Research Councils UK for funding under the Rural Economy and Land Use Programme.

References (not in order yet)

1. Luthria, DL, Mukhopadhyay, S, Krizek, DT (2006) Content of total phenolics and phenolic acids in tomato (Lycopersicon exculentum Mill.)fruits as influenced by cultivar and solar UV radiation. Journal of food composition and analysis, 19 771777.

2. Wagstaffe A, Hadley P and Battey, NH, Tunnel production of strawberry in the UK: a review, in Proceedings of the 2007 North American Strawberry Symposium, ed by Takeda F, Handley DT and Poling EB, Kemptville, Canada. North American Strawberry Growers Association. pp 23-28 (2008).

3. Tsormpatsidis E, Henbest RGC, Davis FJ, Battey NH, Hadley P and Wagstaffe A, UV irradiance as a major influence on growth, development and secondary products of commercial importance in Lollo Rosso lettuce 'Revolution' grown 
under polyethylene films. Environ Exp Bot doi:10.1016/j.envexbot.2007.12.002 (2008).

4. Hannum, SM (2004) Potential impact of strawberries on human health: a review of the science. Critical Reviews in Food Science and Nutrition 44, 1-17.

5. Beattie, J, Crozier, A and Duthie, GG (2005) Potential health benefits of berries. Current Nutrition \& Food Science 1, 71-86

6. Wang SY and Zheng W, Effect of plant growth temperature on antioxidant capacity in strawberry. J Agr Food Chem 49: 4977-4982 (2001).

7. Wang SY, Bunce JA, Maas JL, Elevated carbon dioxide increases contents of antioxidant compounds in field-grown strawberries. J Agr Food Chem 51: 43154320 (2003).

8. Wang SY and Lin HS, Compost as a soil supplement increases the level of antioxidant compounds and oxygen radical absorbance capacity in strawberries. $J$ Agr Food Chem 51: 6844-6850 (2003).

9. Singleton, VL and Rossi JA, Colorimetry of total phenolics with phosphomolybdic-phosphotungstic reagents, Am. J. Enol. Vitic. 16: 144-158 (1965).

10. Gil MI, Holcroft DM and Kader AA, Changes in strawberry anthocyanins and other polyphenols in response to carbon dioxide treatments. J Agr Food Chem 45: 1662-1667(1997).

11. Wang SY and Lin HS, Antioxidant activity in fruits and leaves of blackberry, raspberry, and strawberry varies with cultivar and developmental stage. J Agr Food Chem 48: 140-146 (2000).

12. Wagstaffe A, Hadley P and Battey, NH, Tunnel production of strawberry in the UK: a review, in Proceedings of the 2007 North American Strawberry Symposium, ed by Takeda F, Handley DT and Poling EB, Kemptville, Canada. North American Strawberry Growers Association. pp 23-28 (2008).

13. García-Macías P, Ordidge M, Vysini E, Waroonphan S, Battey NH, Gordon MH, Hadley P, John P, Lovegrove JA and Wagstaffe A, Changes in the flavonoid and phenolic acid contents and antioxidant activity of red leaf lettuce (Lollo Rosso) due to cultivation under plastic films varying in ultraviolet transparency. Journal of Agricultural and Food Chemistry 55: 10168-10172 (2007).

14. Tsormpatsidis E, Henbest RGC, Davis FJ, Battey NH, Hadley P and Wagstaffe A, UV irradiance as a major influence on growth, development and secondary products of commercial importance in Lollo Rosso lettuce 'Revolution' grown under polyethylene films. Environ Exp Bot doi:10.1016/j.envexbot.2007.12.002 (2008).

15. Moyer, RA, Hummer, KE, Finn, CE, Frei, B and Wrolstad, RE (2002) Anthocyanins, phenolics, and antioxidant capacity in diverse small fruits: Vaccinium, Rubus and Ribes, J Agric, Food Chem. 50, 519-525

16. Kalt, W, Howell, A, Duy, JC, Forney, CF, and McDonald, JE (2001) Horticultural factors affecting antioxidant capacity of blueberries and other small fruit. HortTechnology 11, 523-528

17. Brat, P, George, S, Bellamy, A, Du Chaffaut, L, Scalbert, A, Mennen, L, Arnault, N, and Amiot, MJ (2006) Daily polyphenol intake in France from fruit and vegetables. Journal of Nutrition 136): 2368-2373 
228

229 
230 Table 1 Phenolic content of lettuce

\begin{tabular}{|r|c|c|c|c|}
\hline Filter & Total Phenolics & Anthocyanin & Luteolin & Quercetin \\
\hline & mg GAE / g FW & $\begin{array}{c}\mu \mathrm{g} \text { cyanidin / } \\
\text { g FW }\end{array}$ & $\mu \mathrm{g} / \mathrm{g} \mathrm{FW}$ & $\mu \mathrm{g} / \mathrm{g} \mathrm{FW}$ \\
\hline Lollo Rosso & & & & \\
\hline 26 July & & & & \\
\hline Block & $0.75 \pm 0.03^{\mathrm{a}}$ & $15.71 \pm 0.89^{\mathrm{a}}$ & $4.47 \pm 1.63^{\mathrm{a}}$ & $33.18 \pm 2.27^{\mathrm{a}}$ \\
\hline Low & $0.88 \pm 0.06^{\mathrm{a}}$ & $33.50 \pm 1.53^{\mathrm{b}}$ & $8.05 \pm 0.24^{\mathrm{b}}$ & $56.08 \pm 7.51^{\mathrm{a}}$ \\
\hline Window & $1.50 \pm 0.13^{\mathrm{b}}$ & $127.09 \pm 21.05^{\mathrm{c}}$ & $26.42 \pm 3.43^{\mathrm{c}}$ & $213.03 \pm 34.6^{\mathrm{b}}$ \\
\hline Lollo Biondo & & & & \\
\hline 25 July & & & & \\
\hline Block & $0.62 \pm 0.06^{\mathrm{a}}$ & n.d. & n.d. & $16.49 \pm 3.33^{\mathrm{a}}$ \\
\hline Low & $0.66 \pm 0.02^{\mathrm{a}}$ & n.d. & n.d. & $17.58 \pm 2.11^{\mathrm{a}, \mathrm{b}}$ \\
\hline Window & $0.65 \pm 0.03^{\mathrm{a}}$ & n.d. & n.d. & $27.44 \pm 2.26^{\mathrm{b}}$ \\
\hline
\end{tabular}

231

232

233

n.d. $=$ not detected 
234 Table 2. Phenolic contents of strawberry, raspberry and blueberry grown under plastic

235 films of three different UV transparencies. The crops were harvested at the dates shown,

236 as described in Materials and Methods

\begin{tabular}{|c|c|c|c|c|}
\hline & Film & Total Phenolics & Anthocyanin & $\underset{2}{\text { Phenolic acid }}$ \\
\hline \multicolumn{5}{|l|}{ Strawberry } \\
\hline Elsanta & & mg GAE / g FW & $\mu \mathrm{g} / \mathrm{g} \mathrm{FW}$ & $\mu \mathrm{g} / \mathrm{g} \mathrm{FW}$ \\
\hline \multicolumn{5}{|l|}{ Year 1} \\
\hline \multirow{3}{*}{$\begin{array}{c}\text { Crop 1 } \\
\text { 15 June } \\
\text { Commercial } \\
\text { ripeness } \\
\end{array}$} & Block & $2.98 \pm 0.12^{\mathrm{a}}$ & $146.5 \pm 3.0^{\mathrm{a}}$ & $198.5 \pm 25.9^{\mathrm{a}}$ \\
\hline & Low & $3.46 \pm 0.14^{b}$ & $170.1 \pm 7.4^{\mathrm{b}}$ & $263.6 \pm 27.1^{b, c}$ \\
\hline & Window & $3.36 \pm 0.03^{b, d}$ & $162.9 \pm 8.6^{b}$ & $239.2 \pm 3.4^{\mathrm{b}}$ \\
\hline \multirow{3}{*}{ Fully ripe } & Block & $2.77 \pm 0.21^{\mathrm{c}}$ & $209.4 \pm 1.5^{\mathrm{c}}$ & $255.4 \pm 31.6^{b, c}$ \\
\hline & Low & $3.28 \pm 0.05^{\mathrm{d}}$ & $249.0 \pm 10.7^{\mathrm{d}}$ & $346.6 \pm 40.0^{\mathrm{d}}$ \\
\hline & Window & $3.01 \pm 0.11^{\mathrm{a}}$ & $219.0 \pm 2.8^{\mathrm{c}, \mathrm{d}}$ & $295.7 \pm 9.2^{\mathrm{c}}$ \\
\hline \multirow{3}{*}{$\begin{array}{c}\text { Crop } 2 \\
3 \text { July } \\
\text { Commercial } \\
\text { ripeness } \\
\end{array}$} & Block & $2.83 \pm 0.15^{\mathrm{a}}$ & $202.9 \pm 7.8^{\mathrm{a}}$ & $425.7 \pm 17.3^{\mathrm{a}}$ \\
\hline & Low & $2.96 \pm 0.03^{b}$ & $187.4 \pm 6.0^{b}$ & $490.8 \pm 7.8^{b}$ \\
\hline & Window & $3.28 \pm 0.18^{\mathrm{c}}$ & $199.5 \pm 16.6^{\mathrm{a}, \mathrm{b}}$ & $534.5 \pm 57.6^{b}$ \\
\hline \multirow{3}{*}{ Fully ripe } & Block & $2.34 \pm 0.05^{\mathrm{d}}$ & $261.9 \pm 8.7^{\mathrm{c}}$ & $312.2 \pm 12.2^{\mathrm{c}}$ \\
\hline & Low & $2.88 \pm 0.10^{\mathrm{a}, \mathrm{b}}$ & $297.5 \pm 5.5^{\mathrm{d}}$ & $392.8 \pm 31.0^{\mathrm{d}}$ \\
\hline & Window & $2.64 \pm 0.06^{\mathrm{e}}$ & $268.7 \pm 8.8^{\mathrm{c}}$ & $351.2 \pm 30.0^{\mathrm{d}}$ \\
\hline \multicolumn{5}{|l|}{ Year 2} \\
\hline \multirow{3}{*}{$\begin{array}{l}\text { Crop } 1 \\
25 \text { June }\end{array}$} & Block & $2.80 \pm 0.14^{\mathrm{a}}$ & $220.5 \pm 2.0^{\mathrm{a}}$ & $406.6 \pm 19.7^{\mathrm{a}}$ \\
\hline & Low & $3.07 \pm 0.09^{\mathrm{a}, \mathrm{b}}$ & $226.63 \pm 3.8^{\mathrm{a}, \mathrm{b}}$ & $501.8 \pm 1.0^{\mathrm{b}}$ \\
\hline & Window & $3.24 \pm 0.05^{\mathrm{b}}$ & $241.3 \pm 7.9^{b}$ & $510.8 \pm 23.6^{b}$ \\
\hline \multirow{3}{*}{$\begin{array}{l}\text { Crop } 2 \\
23 \text { July }\end{array}$} & Block & $2.89 \pm 0.13^{\mathrm{a}}$ & $298.1 \pm 16.8^{\mathrm{a}}$ & $583.6 \pm 45.7^{\mathrm{a}}$ \\
\hline & Low & $2.99 \pm 0.02^{\mathrm{a}}$ & $296.6 \pm 1.8^{\mathrm{a}}$ & $640.6 \pm 18.0^{\mathrm{a}}$ \\
\hline & Window & $3.16 \pm 0.13^{\mathrm{b}}$ & $315.5 \pm 28.9^{\mathrm{a}}$ & $646.4 \pm 73.6^{\mathrm{a}}$ \\
\hline \multirow{3}{*}{$\begin{array}{l}\text { Everest } \\
13 \text { August }\end{array}$} & Block & $3.07 \pm 0.06^{\mathrm{a}}$ & $329.6 \pm 16.7^{\mathrm{a}}$ & $172.0 \pm 12.7^{\mathrm{a}}$ \\
\hline & Low & $3.47 \pm 0.14^{b}$ & $343.8 \pm 10.8^{\mathrm{a}}$ & $187.7 \pm 10.8^{\mathrm{a}, \mathrm{b}}$ \\
\hline & Window & $3.67 \pm 0.06^{b}$ & $353.3 \pm 9.3^{\mathrm{a}}$ & $199.5 \pm 15.1^{b}$ \\
\hline \multicolumn{5}{|l|}{ Raspberry } \\
\hline \multicolumn{5}{|l|}{ Year 1} \\
\hline \multirow{3}{*}{$\begin{array}{c}\text { Tulameen } \\
11 \text { July }\end{array}$} & Block & $1.34 \pm 0.07^{\mathrm{a}}$ & $357.0 \pm 8.3^{\mathrm{a}}$ & $485.8 \pm 13.4^{\mathrm{a}}$ \\
\hline & Low & $1.45 \pm 0.10^{\mathrm{a}, \mathrm{b}}$ & $311.2 \pm 20.9^{b}$ & $489.8 \pm 9.5^{\mathrm{a}}$ \\
\hline & Window & $1.35 \pm 0.10^{\mathrm{b}}$ & $364.4 \pm 31.2^{\mathrm{a}}$ & $483.6 \pm 22.3^{\mathrm{a}}$ \\
\hline \multirow{3}{*}{$\begin{array}{c}\text { Joan Squire } \\
7 \\
\text { September }\end{array}$} & Block & $2.13 \pm 0.21^{\mathrm{a}}$ & $384.7 \pm 13.5^{\mathrm{a}}$ & $554.7 \pm 111.3^{\mathrm{a}}$ \\
\hline & Low & $2.17 \pm 0.29^{\mathrm{a}}$ & $362.9 \pm 7.1^{b}$ & $603.0 \pm 144.5^{\mathrm{a}}$ \\
\hline & Window & $2.25 \pm 0.22^{\mathrm{a}}$ & $393.5 \pm 16.7^{\mathrm{a}}$ & $606.3 \pm 92.7^{\mathrm{a}}$ \\
\hline
\end{tabular}


9

\begin{tabular}{|l|l|l|l|l|}
\hline & & & & \\
\hline Blueberry & & & & \\
\hline Year 1 & Block & $2.65 \pm 0.17^{\mathrm{a}}$ & $1052.3 \pm 154.5^{\mathrm{a}}$ & $1510.1 \pm 30.6^{\mathrm{a}}$ \\
\hline 31 July & Low & $3.07 \pm 0.08^{\mathrm{b}}$ & $1132.7 \pm 113.2^{\mathrm{a}}$ & $1524.6 \pm 26.8^{\mathrm{a}}$ \\
\hline & Window & $3.25 \pm 0.07^{\mathrm{c}}$ & $1507.9 \pm 54.4^{\mathrm{b}}$ & $1543.4 \pm 26.6^{\mathrm{a}}$ \\
\hline & & & & \\
\hline Year 2 & Block & $2.93 \pm 0.19^{\mathrm{a}}$ & $553.9 \pm 53.6^{\mathrm{a}}$ & $833.0 \pm 20.9^{\mathrm{a}}$ \\
\hline 17 July & Low & $3.46 \pm 0.17^{\mathrm{b}}$ & $778.4 \pm 123.7^{\mathrm{b}}$ & $861.9 \pm 14.5^{\mathrm{a}, \mathrm{b}}$ \\
\hline & Window & $2.88 \pm 0.29^{\mathrm{a}}$ & $596.4 \pm 151.9^{\mathrm{a}}$ & $872.3 \pm 23.5^{\mathrm{b}}$ \\
\hline
\end{tabular}

$237{ }^{1}$ Anthocyanin was determined as $\mu$ g pelargonidin / g FW in strawberry, $\mu \mathrm{g}$ cyanidin / g

238 FW in raspberry and $\mu \mathrm{g}$ malvidin / $\mathrm{g}$ FW in blueberry.

$239{ }^{2}$ Phenolic acid was determined as ellagic acid in strawberry and raspberry, and is

240 expressed as $\mu \mathrm{g}$ ellagic acid / g FW in strawberry and raspberry, and determined as

241 hydroxycinnamic acids in blueberry, and expressed as $\mu \mathrm{g}$ caffeic acid equivalents/g FW

242 in blueberry. 